\title{
PROPOSAL FOR A CLASSIFICATION OF OOCYTES AND FOLLICLES IN THE MOUSE OVARY
}

\author{
TORBEN PEDERSEN AND HANNAH PETERS
}

\author{
The Finsen Laboratory, Copenhagen, Denmark
}

(Received 27th May 1968)

The need to develop a common terminology to describe the components of the ovary has been felt for some time (Gatz, 1955; Wischnitzer, 1966). A standard nomenclature would greatly facilitate the comparison of results relating to the development of the ovary and follicle growth under normal as well as experimental conditions. Various classifications have been used to describe stages of oocyte and follicle development. Some authors use the shape of the granulosa cells and the number of layers surrounding the oocyte as the main characteristic (Engle, 1927; Mandl \& Zuckerman, 1950; Adams \& Hertig, 1964; Hadek, 1965). Others take the largest diameter or the volume of the follicles as the distinguishing criterion (Boling, Blandau, Soderwall \& Young, 1941; Paesi, 1949), while still others use a combination of the number of cell layers and follicle diameter to describe the stage of follicle development (Bullough, 1942; Ingram, 1959; Knigge \& Leathem, 1956). Variations in the size of the oocyte in addition to the variation in size of the follicle has only rarely been taken into account to describe the follicle development (Mandl \& Zuckerman, 1952; Peters \& Borum, 1961; Brambell, 1956). Terms like primordial follicles, small follicles and primary follicles have been used to describe follicles with a single layer of cells attached to the oocytes. Secondary and growing follicles described follicles with several layers of cells surrounding the oocyte. Tertiary, large, vesicular, Graafian or preovulatory follicles are some of the terms used for various later stages of follicle growth. Clearly, a more accurate classification is needed to define the stages of oocyte and follicle development.

We would like to communicate a classification which has proved useful in evaluating and comparing changes in oocyte and follicle growth under different conditions. The classification is based on (1) the size of the oocyte in follicles of different stages of development, (2) on the size of the follicle defined by the number of cells constituting the follicular envelope, and (3) on the morphology of the follicle (Text-fig. 1).

\section{The oocyte}

The oocytes are divided into:

(a) the small oocyte, a cell with a diameter of less than $20 \mu$;

(b) the growing oocyte, a cell which has begun to grow but has not reached its final size yet (diameter between 20 and $70 \mu$ );

(c) the large oocyte, a cell which has reached its final size (diameter $70 \mu$ ). 
2 and 3. The envelope and morphology of the follicles

The follicles are divided into three main groups: small, medium and large follicles. These are further subdivided according to the number of follicle cells counted on the largest cross-section of the follicle (section thickness $5 \mu$ ) and taking its morphological appearance into account.

Small follicles. Type 1: consists of a small oocyte with no follicle cells attached to its surface.

Type 2: a small oocyte has a few cells attached to its cell surface, but not a complete ring of cells (Pl. 1, Fig. 1).

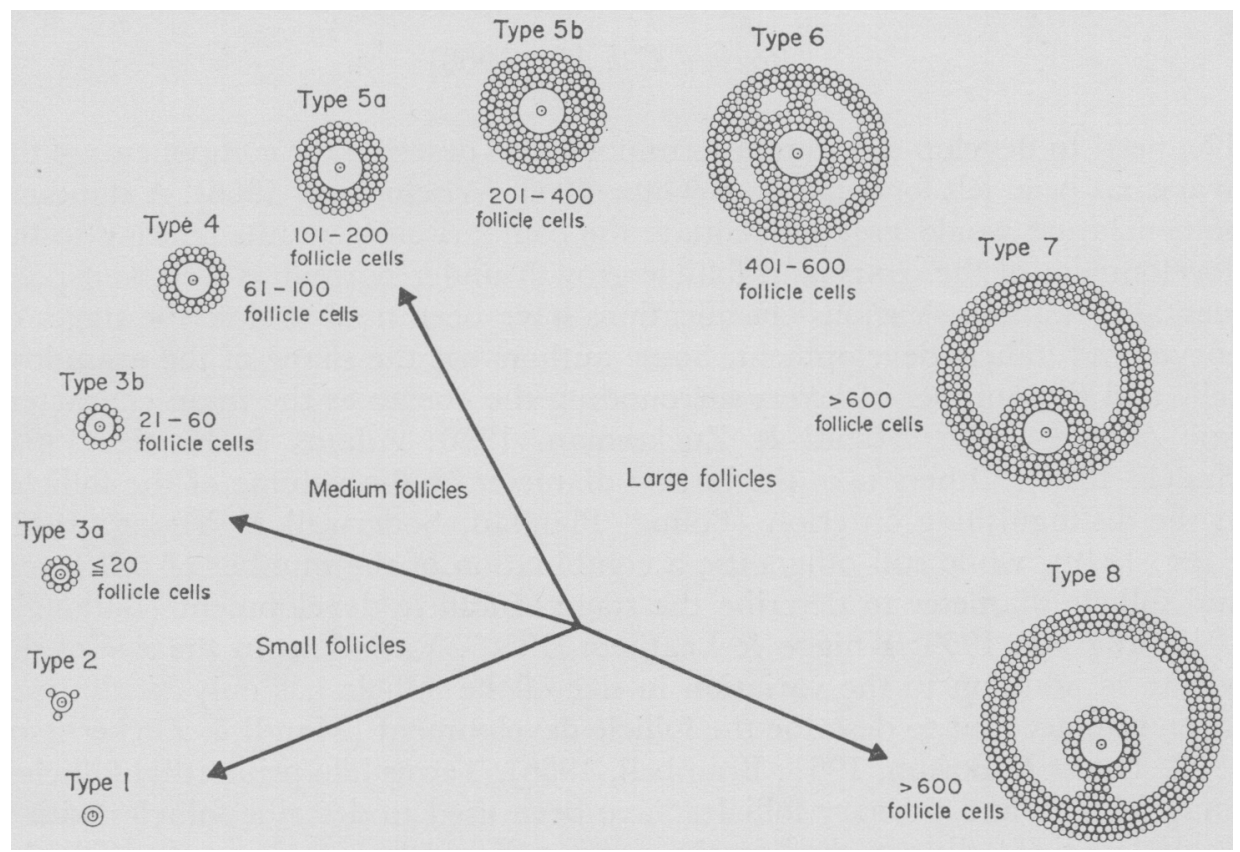

TEXT-FIG. 1. Classification of follicles.

Type 3a: a complete ring of follicle cells surrounds the oocyte which is usually small or might have started to grow. There are not more than 20 follicle cells on the largest cross-section (Pl. 1, Figs. 1 and 2).

Medium-sized follicles. Type 3b: One complete ring of follicle cells surrounds a growing oocyte. There are 21 to 60 cells on the largest cross-section (P1. 1, Fig. 2).

Type 4: Two layers of follicle cells surround a growing oocyte. There are 61 to 100 cells on the largest cross-section (Pl. 1, Figs. 2 and 3).

\section{EXPLANATION OF PLATE 1}

Fic. 1. Ovary of a 47-day-old mouse. Several small follicles and four follicles of Type 4. $\times 250$.

Fig. 2. Ovary of a 47-day-old mouse. A small follicle Type 3a and medium-sized follicles Types $3 \mathrm{~b}$ and 4 are seen. $\times 250$.

Fig. 3. Ovary of a 33-day-old mouse. Medium-sized (Type 4) and large follicles (Types 5a, $5 \mathrm{~b}$ and 6$)$ are seen. $\times 100$.

FIc. 4. Ovary of a 47-day-old mouse. A typical large follicle of Type $7 . \times 100$. 
PIATE 1

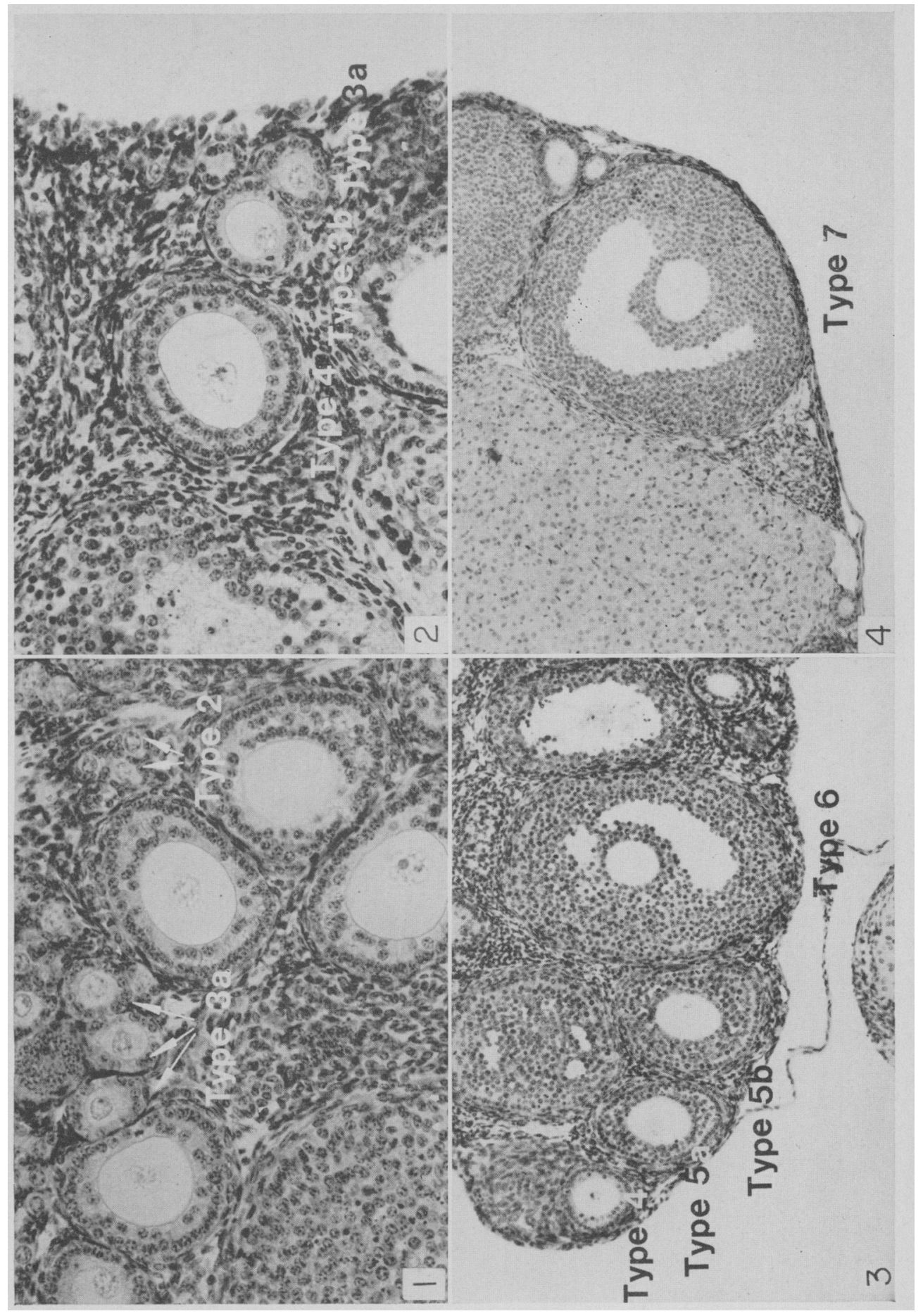

fracing $1 \% .556$ 
Type 5a: is a transitory stage between medium-sized and large follicles. In some of the follicles the oocyte is still less than $70 \mu$, in others it has reached its full size already. This type has three layers of follicle cells and 101 to 200 cells on the largest cross-section (Pl. 1, Fig. 3).

Large follicles. Type $5 \mathrm{~b}$ : a fully grown oocyte is surrounded by many layers of follicle cells. There are 201 to 400 cells on the largest cross-section. No follicle fluid (Pl. 1, Fig. 3).

Type 6: a large oocyte with many layers of cells. The follicle cells are separated by scattered areas of fluid. On the largest cross-section 401 to 600 cells are seen (Pl. 1, Fig. 3).

Type 7: a follicle with a single cavity containing follicle fluid. There are more than 600 cells on the largest cross-section. The cumulus oophorus (but not the stalk) has formed (Pl. 1, Fig. 4).

Type 8: a large follicle with a single cavity with follicle fluid and a wellformed cumulus stalk. This follicle represents the preovulatory follicle.

This classification has been used in the quantitative analysis of the ovary for total oocyte counts as well as to determine the normal distribution of different follicle stages at varying ages or a shift in this distribution after treatment.

\section{REFERENCES}

Adams, E. G. \& Hertig, A. T. (1964) Studies on the guinea pig oocytes. I. Electron microscopic observations on the development of cytoplasmatic organelles in oocytes of primordial and primary follicles. F. Cell Biol. 21, 397.

Boling, J. L., Blandau, R. J., Soderwall, A. L. \& Young, W. C. (1941) Growth of the Graafian follicle and the time of ovulation in the albino rat. Anat. Rec. 79, 313.

Brambell, F. W. R. (1956) Ovarian changes. In: Marshall's Physiology of Reproduction, Vol. I, pt 1, p. 397. Ed. A. S. Parkes. Longmans, Green, London.

Bullovgh, W. S. (1942) Mitotic activity in the adult mouse ovary. F. Endocr. 44, 150.

ENGLe, E. T. (1927) A quantitative study of the follicular atresia in the mouse. Am. F. Anat. 39, 187.

Gatz. A. J. (1955) A critique on the discussion of oogenesis in the text books of histology. Turtox News, $33,106$.

HADEK, R. (1965) The structure of the mammalian egg. Int. Rev. Cytol. 18, 29.

INGRAM, D. L. (1959) The effect of oestrogen on the atresia of ovarian follicles. F. Endocr. 19, 123.

KNIGGE, K. M. \& LEATHEM, J. H. (1956) Growth and atresia of follicles in the ovary of the hamster. Anat. Rec. 124, 680.

Mande, A. M. \& Zuckerman, S. (1950) The numbers of normal and atretic ova in the mature rat. 7. Endocr. 6, 426.

Mande, A. M. \& Zuckerman, S. (1952) The growth of the oocyte and follicle in the adult rat. $\mathcal{F}$. Endocr. 8, 126.

Paesi, F. J. A. (1949) The relation between the rate of growth of follicle and the shape of the frequency curve presenting their variability in size. Acta endocr., Copenh. 3, 173.

Peters, H. \& Borum, K. (1961) The development of mouse ovaries after low dose irradiation at birth. Int. 7. Radiat. Biol. 3, 1.

Wischnitzer, S. (1966) The maturation of the ovum and growth of the follicle in the mouse ovary. A phase contrast microscope study. Growth, 30,239. 